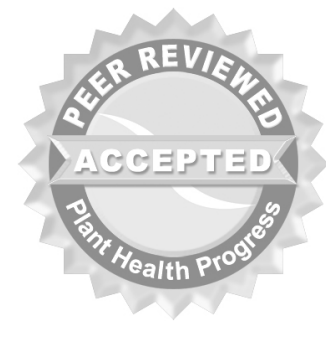

(C) 2006 Plant Management Network.

Accepted for publication 31 July 2006. Published 20 October 2006.

\title{
Effect of Row Covers on Suppression of Bacterial Wilt of Muskmelon in Iowa
}

\author{
Daren S. Mueller, Mark L. Gleason, Adam J. Sisson, and J on M. \\ Massman, Department of Plant Pathology, I owa State University, \\ Ames 50011
}

Corresponding author: Daren S. Mueller. dsmuelle@iastate.edu

Mueller, D. S., Gleason, M. L., Sisson, A. J., and Massman, J. M. 2006. Effect of row covers on suppression of bacterial wilt of muskmelon in Iowa. Online. Plant Health Progress doi: 10.1094/PHP-2006-1020-02-RS.

\begin{abstract}
Spun polyester row covers, alone and in combination with insecticides, were evaluated for management of bacterial wilt of muskmelon at three locations in lowa during 2003 and 2004 . Following removal of row covers at bloom, more spotted cucumber beetles were counted in the plots with row covers than in the non-covered plots. Row covers delayed the onset of bacterial wilt symptoms and reduced bacterial wilt incidence. In both years, row covers increased both number and yield of marketable melons. There were no significant differences in beetle counts or melon yield among insecticide treatments in 2003. In 2004, however, each of the insecticide treatments had more marketable melons than the nontreated control. Row covers may enable cucurbit growers to reduce reliance on insecticides for managing bacterial wilt.
\end{abstract}

\section{I ntroduction}

Bacterial wilt is among the most damaging diseases of cucurbit crops (Fig. 1) and can cause losses up to 70\% (13). The pathogen, Erwinia tracheiphila, is vectored by two species of cucumber beetles, the striped cucumber beetle (Acalymma vittatum) and the spotted cucumber beetle (Diabrotica undecimpunctate howardi) (9). The bacteria enter the vascular system and block water movement, causing plants to wilt and die.

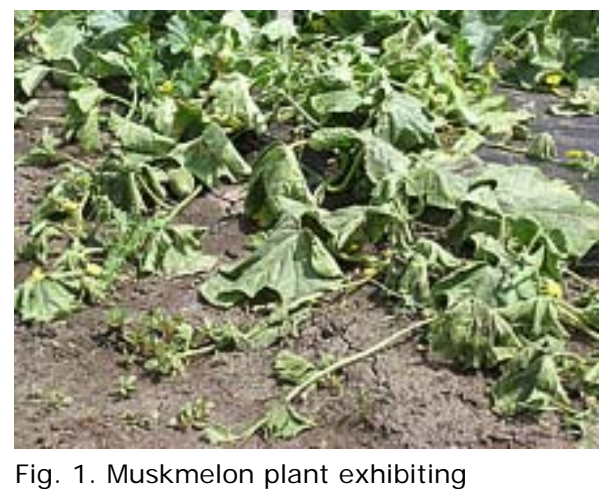

Fig. 1. Muskmelon plant exhibiting symptoms of bacterial wilt.

Currently, bacterial wilt management depends on insecticide applications to control cucumber beetles. Cucurbit management guides recommend frequent insecticide applications, beginning when beetle emergence is first detected and continuing throughout the season (4). This intensive spray regimen can pose serious risk to applicators and to non-target organisms.

One management strategy to reduce reliance on insecticide sprays against cucumber beetles may be plastic or semi-permeable cloth row covers. Row covers are placed over the crop row and the edges are secured with soil (Fig. 2). While it is in place, the material provides a barrier to most insect pests not already present on plants or in the soil. Row covers have led to earlier harvest 
and increased yields through the exclusion of harmful insects (1), reduction of other insect-vectored diseases $(2,12,14)$, and increased early-season soil temperatures $(3,11)$. Row covers can reduce pesticide applications, which can save money and decrease environmental damage.

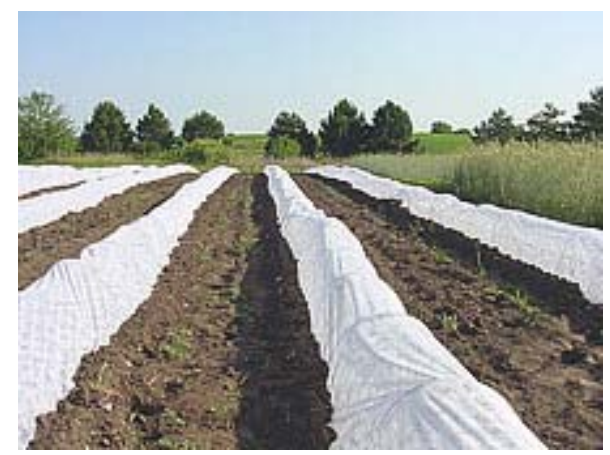

Fig. 2. Spun polyester row covers protecting young muskmelon plants.

No previous reports have focused on the impact of row covers on the population of cucumber beetles in a field, and on suppression of bacterial wilt on muskmelon. The objective of this study was to determine the effect of row covers in combination with insecticides on bacterial wilt incidence in muskmelon.

\section{Field Setup and Plot Maintenance}

Muskmelon seeds (cv. Athena) were planted in the greenhouse approximately one month prior to transplanting in the field (Table 1). Three days prior to transplanting, seedlings were placed outdoors under shade to acclimate them. Plots were established at Iowa State University research farms near Armstrong (southwestern Iowa), Gilbert (central Iowa), and Muscatine (eastern Iowa) in 2003 and 2004 (Table 1). The experiment was set up in a splitplot, randomized complete block design with four replications. The main plot treatment was row cover; one field at each location received row covers, whereas the other field did not. Fields at each farm were separated by a minimum of $1000 \mathrm{ft}$ in order to minimize the impact of each field on beetle populations in the other field. Four insecticide treatments were subplots and were randomized within four blocks (replications) of each field. Each subplot consisted of three rows spaced $8 \mathrm{ft}$ apart. Eight to 10 muskmelons were transplanted $2 \mathrm{ft}$ apart in each row. Within rows, 10 -ft-long gaps separated subplots. All rows were covered in black plastic mulch prior to transplanting.

Table 1. Dates for transplanting, removing row covers, and the initiation of harvest for three locations in Iowa.

\begin{tabular}{|l|l|c|c|c|}
\hline \multirow{3}{*}{ Year } & Location & $\begin{array}{c}\text { Transplanting } \\
\text { date }\end{array}$ & $\begin{array}{c}\text { Removed } \\
\text { row cover }\end{array}$ & First harvest \\
\hline 2003 & Armstrong & 19 May & 16 June & 7 August \\
\cline { 2 - 6 } & Gilbert & 20 May & 16 June & 7 August \\
\cline { 2 - 6 } & Muscatine & 21 May & 17 June & 29 July \\
\hline 2004 & Armstrong & 3 June & 2 July & 13 August \\
\cline { 2 - 6 } & Gilbert & 1 June & 1 July & 12 August \\
\cline { 2 - 6 } & Muscatine & 21 May & 14 June & 27 July \\
\hline
\end{tabular}

Fields at Gilbert and Muscatine received overhead irrigation and fields at Armstrong were drip irrigated. Practices for management of fertility, weeds, and fungal diseases followed Iowa State University Extension recommendations. 


\section{Row Cover and I nsecticide Treatments}

Immediately after transplanting, one field at each location was covered with spun cotton row covers (Reemay, Reemay Inc., Old Hickory, TN). Row covers were supported by wire hoops placed every $10 \mathrm{ft}$, and edges of the fabric were covered with soil. The row covers were removed when bloom began and all plants remained uncovered through harvest (Table 1).

Insecticide treatments used in this experiment were: imidacloprid (20 oz/ acre, Admire 2F, Bayer, Kansas City, MO); spinosad (2.5 oz/ acre, Entrust, Dow AgroSciences, Indianapolis, IN); a conventional control (carbaryl at 1 qt/ acre, Sevin, Bayer CropScience, Research Triangle Park, NC) in 2003; or Sevin alternated with bifenthrin ( 5 oz/ acre, Capture 2EC, FMC Corporation, Philadelphia, PA); and a control (no insecticide applications).

Foliar insecticides were applied with hand pump backpack sprayers (Model 435, Solo, Newport News, VA) equipped with a single TX-18 Cone-J et Tee-J et nozzle tip. All plots except the non-treated control received the first insecticide spray immediately after transplanting in the non-covered field and immediately after row covers were removed in the covered field. Subsequent treatments were applied at 14-day intervals until harvest. For foliar applications, plants were sprayed until runoff. Admire was applied as a drench treatment at transplanting using approximately $10 \mathrm{fl} \mathrm{oz}$ of water per plant.

Row covers and insecticides were analyzed by two-way analysis of variance (ANOVA) using the general linear models procedure (PROC GLM) of SAS, version 9.0 (SAS Institute Inc., Cary, NC). A significant $(P<0.05)$ year $\times$ row cover and year $\times$ insecticide interaction for most measured variables was found, so data from each year are presented separately. Because there were differences in the number of insecticide applications applied to the cover and non-covered plots, combinations of row cover and insecticide treatments were analyzed using individual t-tests. Differences in beetle populations were analyzed for before and after removal of row covers.

\section{Beetle Populations}

Data were taken from the middle row of each subplot. Once each week, striped and spotted cucumber beetles (Fig. 3) were counted on five arbitrarily selected plants per plot. No cucumber beetles were observed on plants under Reemay row covers. The population of striped and spotted cucumber beetles ranged from zero to 1.9 beetles per plant in 2003 (Fig. 4) and zero to 5.3 beetles per plant in 2004 (Fig. 5). Prior to the removal of row covers, there were significantly more striped cucumber beetles in the non-covered plots (average of 0.45 and 1.19 beetles per plant in 2003 and 2004, respectively) compared to the covered plots. However, after row covers were removed in both years, fields with covered rows averaged significantly $(\mathrm{P}<0.05)$ more spotted cucumber beetles than rows that were not covered and had significantly more striped cucumber beetles in 2004.
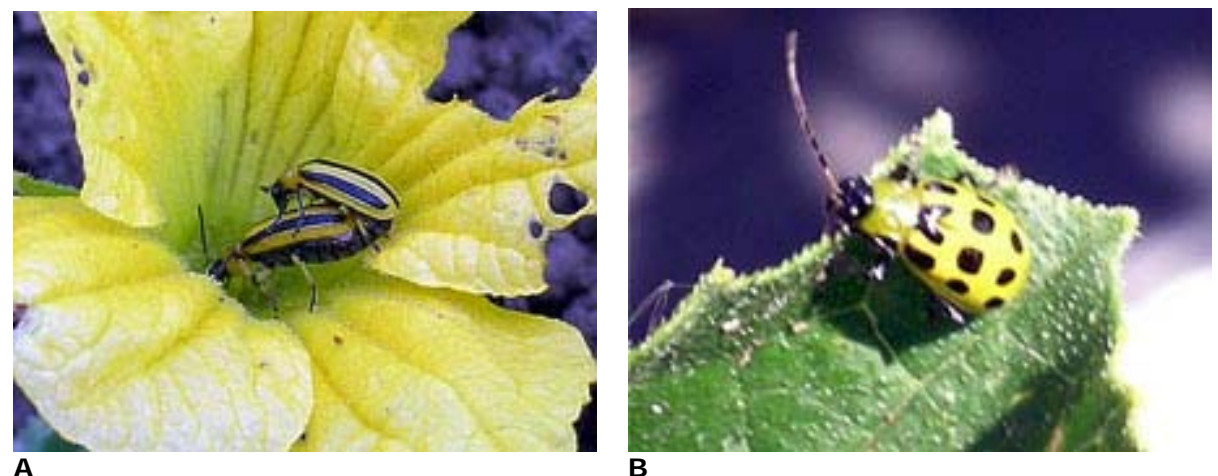

Fig. 3. Striped (A) and spotted (B) cucumber beetles, vectors for bacterial wilt pathogen.

Prior to the removal of the row cover in 2003, insecticide treatments did not result in fewer beetles compared to the non-treated control. However, in 2004 the conventional insecticide and Admire treatments reduced beetle populations 
compared to the Entrust treatment and the non-treated control. After removal of row covers, there were no significant differences between any insecticide treatment and the non-treated control; however, some significant differences occurred among insecticide treatments (Figs. 4 and 5).
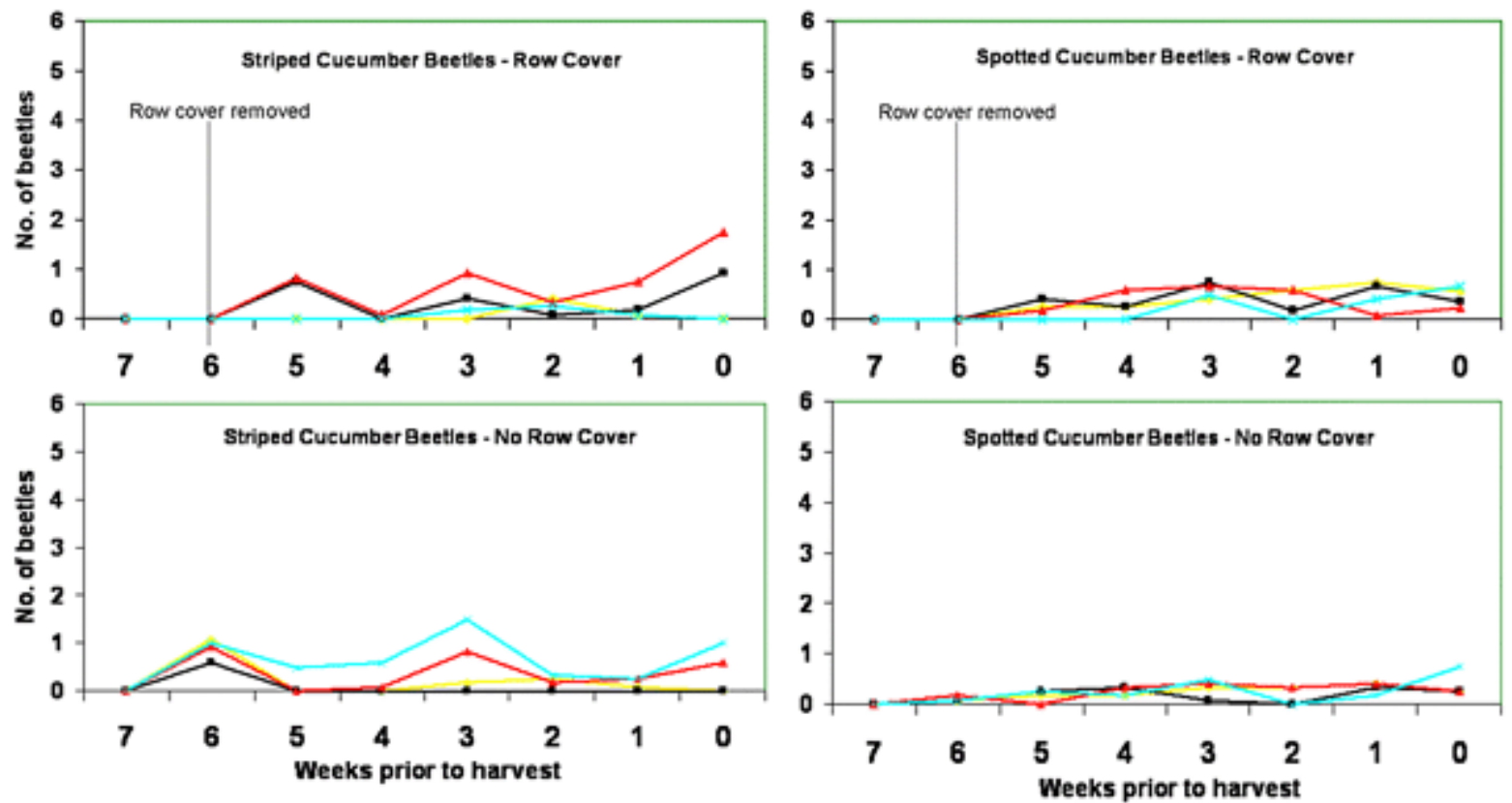

\section{Admire $\rightarrow$ Entrust $\rightarrow$ Conv - Check}

Fig. 4. Effect of row covers and insecticides on striped and spotted cucumber beetles averaged across experiments at I owa State University research farms near Armstrong, Gilbert, and Muscatine, IA in 2003.
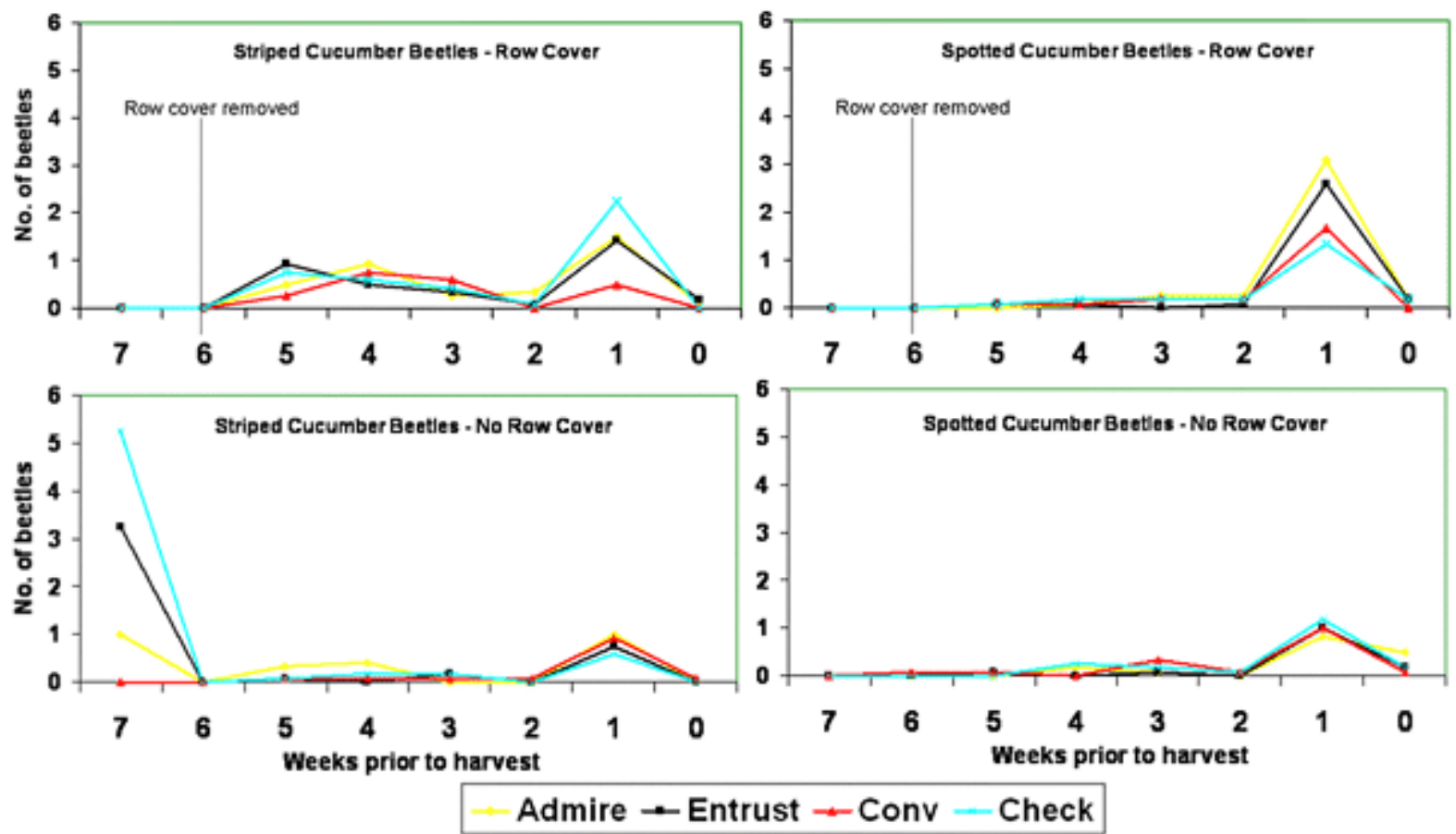

Fig. 5. Effect of row covers and insecticides on striped and spotted cucumber beetles averaged across experiments at I owa State University research farms near Armstrong, Gilbert, and Muscatine, IA in 2004. 


\section{Bacterial Wilt}

Data were taken from the middle row of each subplot. Once each week, the number of plants per plot that exhibited symptoms of bacterial wilt was

recorded. Plants were considered wilted when at least one shoot exhibited wilt symptoms. Percent wilt on the first harvest date and 10 days earlier were analyzed using two-way ANOVA and Fisher's protected LSD with $\mathrm{P}=0.05$. To determine whether row cover or insecticides delayed bacterial wilt, slopes were calculated and approximate dates on which wilt exceeded $5 \%$ were determined using linear interpolation. Slopes were analyzed using two-way ANOVA and Fisher's protected LSD with $\mathrm{P}=0.05$.

In both years, incidence of bacterial wilt at the end of the season was significantly higher in non-covered plots than in plots that had had row covers (Fig. 6). Slopes for disease development were higher in the non-covered plots than in the covered plots (Fig. 6). In 2003, plots with no row covers had $2 \%$ wilt 36 days before harvest, whereas row-covered plots did not exceed $2 \%$ wilt until 1 day before harvest, and incidence of wilt never exceeded $5 \%$ in the plots with row covers (Fig. 6). In 2004, plots with no row covers had $2 \%$ wilt 34 days before harvest, whereas plots with row covers had $2 \%$ wilt 28 days before harvest, and row covers delayed attainment of 5\% incidence of wilt for 9 days (19 days before harvest). 


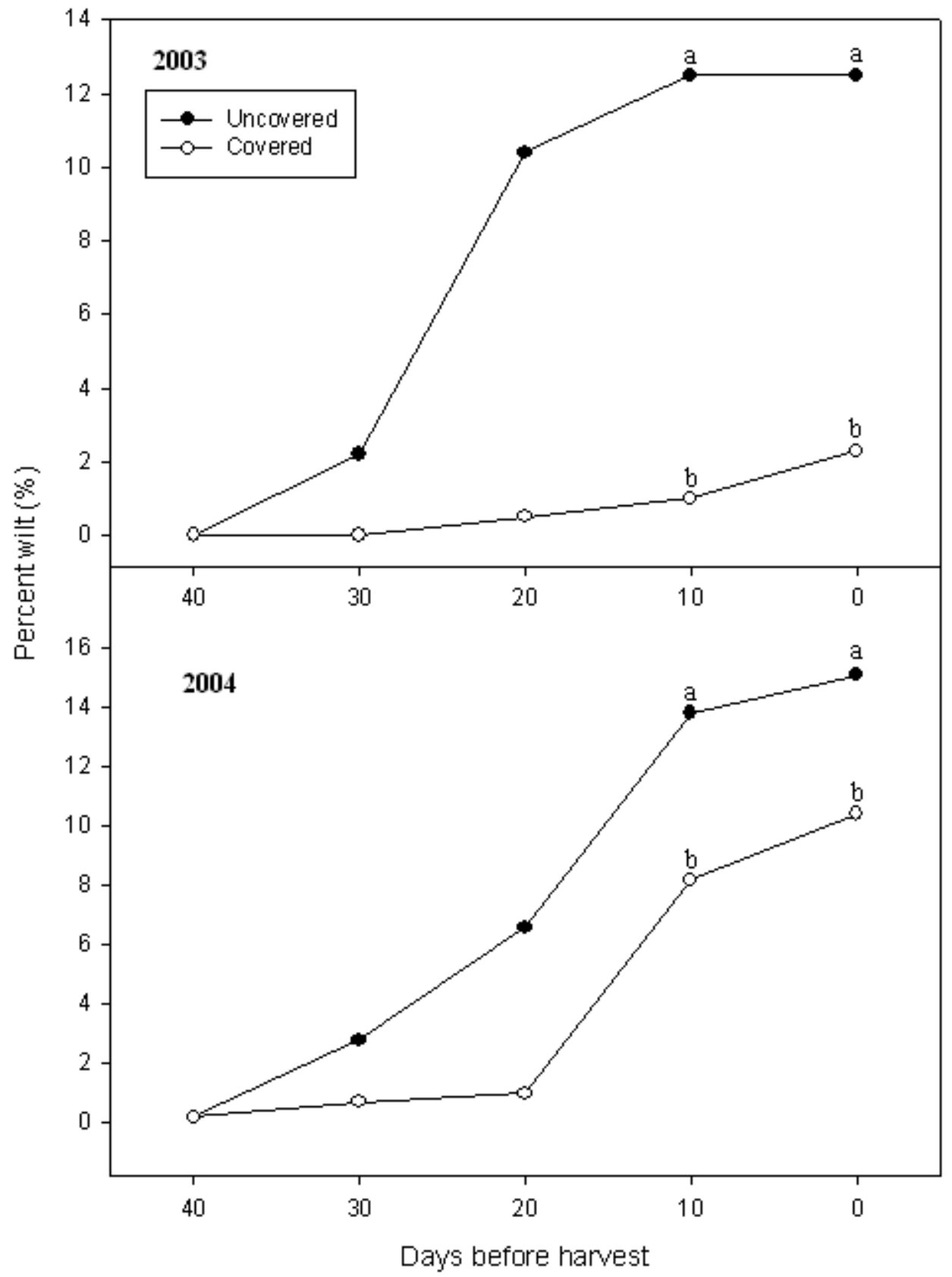

Fig. 6. Percent incidence of wilt on muskmelon plants grown with or without row covers in 2003 and 2004 at lowa State University research farms near Armstrong, Gilbert, and Muscatine, IA. Melons were first harvested between 27 July and 13 August. On the first harvest date or 10 days earlier, means within the same date that do not have a letter in common are significantly different $(P<0.05)$. Row covers were removed between 40 and 45 days prior to the start of harvest.

In 2003, insecticide treatments had no significant effect on incidence of bacterial wilt, either 10 days prior to the first harvest or at the first harvest (Fig. 7). In 2004, the conventional-insecticide treatment had significantly lower incidence of wilt than the non- treated control 10 days prior to the first harvest and at the first harvest (Fig. 7). Plants in the Admire treatment had significantly less wilt than the non-treated control 10 days prior to harvest, but not at harvest. There was no significant difference between the non-treated control and Entrust at either date. Plots that received conventional insecticide and Admire required 13 and 11 days longer, respectively, to exceed 5\% wilt incidence than the nontreated plots (Fig. 7). 


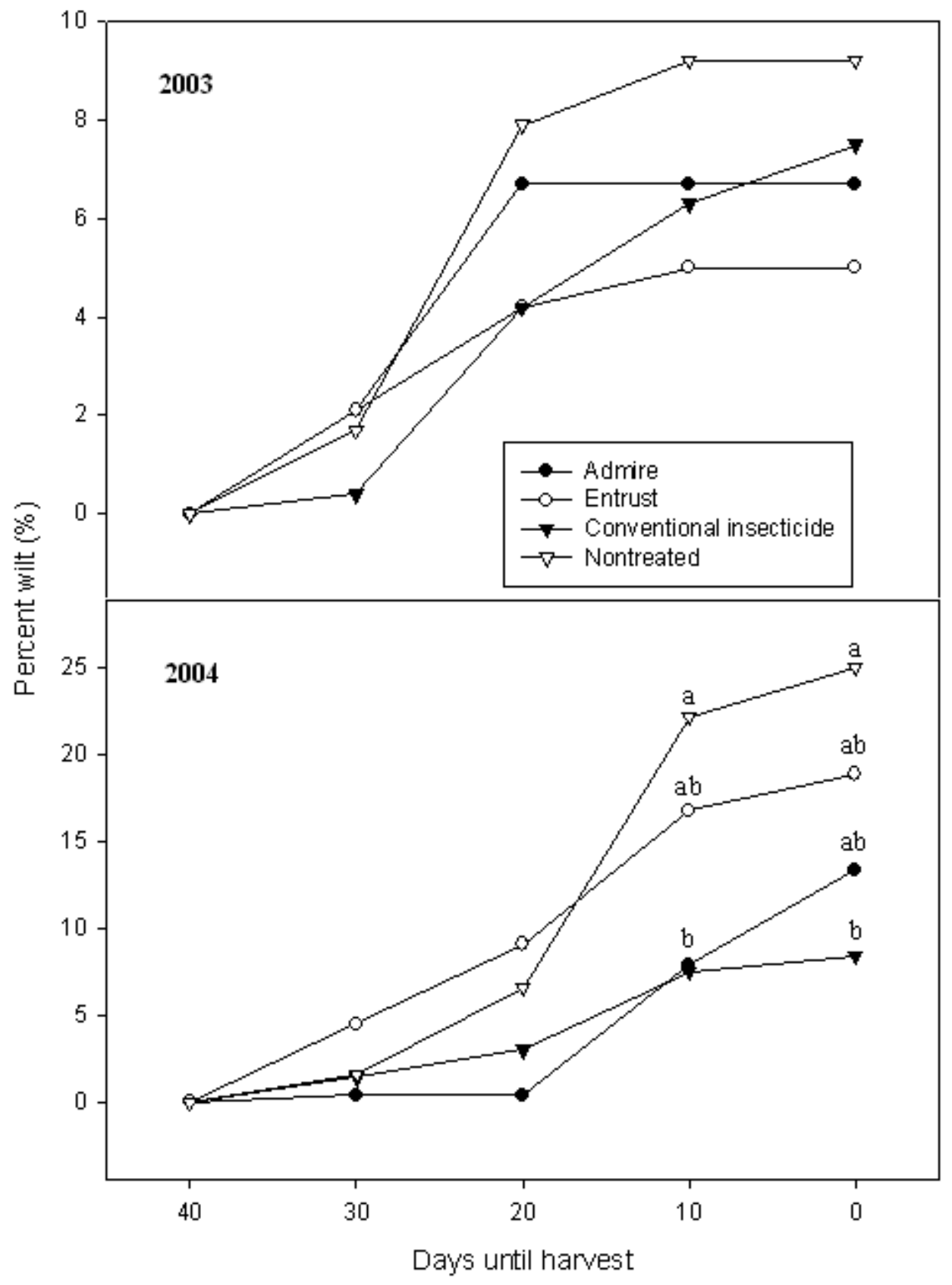

Fig. 7. Percent incidence of wilt on muskmelon plants treated or not treated with insecticides in 2003 and 2004. Melons were first harvested between 27 July and 13 August. On the first harvest date or 10 days earlier, means within the same date without a letter in common are significantly different $(P<0.05)$. Row covers were removed between 40 and 45 days prior to the start of harvest.

\section{Yield}

The number and weight of both marketable and cull melons harvested per plot was assessed twice per week during harvest. In both years, plots with row covers had more marketable yield than plots that were not covered (Table 2). There were no significant differences between insecticide treatments and the non-treated control for melon number or weight in 2003. In 2004, plots treated with Admire, Entrust, and the conventional insecticide had significantly higher yield and more melons than the non-treated control (Table 3). 
Table 2. Effect of row cover on muskmelon production averaged across experiments at I owa State University research farms near Armstrong, Gilbert, and Muscatine, IA in 2003 and 2004.

\begin{tabular}{|l|l|c|c|c|}
\hline \multirow{2}{*}{ Year } & Treatment & $\begin{array}{c}\text { Number of } \\
\text { marketable } \\
\text { melons }^{\mathrm{N}}\end{array}$ & $\begin{array}{c}\text { Weight of } \\
\text { marketable } \\
\text { melons (Ib) }\end{array}$ & $\begin{array}{c}\text { \% } \\
\text { marketable } \\
\text { melons }\end{array}$ \\
\hline 2003 & Covered & $21.5 \mathrm{a}$ & $125.1 \mathrm{a}$ & $72.6 \mathrm{a}$ \\
\cline { 2 - 5 } & Non-covered & $15.6 \mathrm{~b}$ & $91.2 \mathrm{~b}$ & $67.8 \mathrm{a}$ \\
\hline 2004 & Covered & $31.8 \mathrm{a}$ & $166.2 \mathrm{a}$ & $78.2 \mathrm{a}$ \\
\cline { 2 - 5 } & Non-covered & $23.6 \mathrm{~b}$ & $132.8 \mathrm{~b}$ & $69.1 \mathrm{~b}$ \\
\hline
\end{tabular}

$x$ The number of melons and melon weight are presented per subplot (10-ft row segment).

Table 3. Effect of insecticides on muskmelon production averaged across experiments at I owa State University research farms near Armstrong, Gilbert, and Muscatine, IA in 2003 and 2004.

\begin{tabular}{|c|c|c|c|c|}
\hline Year & Treatment & $\begin{array}{c}\text { Number of } \\
\text { marketable } \\
\text { melons }^{x}\end{array}$ & $\begin{array}{l}\text { Weight of } \\
\text { marketable } \\
\text { melons }(\mathrm{lb})^{\mathrm{x}}\end{array}$ & $\begin{array}{c}\% \\
\text { marketable } \\
\text { melons }\end{array}$ \\
\hline \multirow[t]{5}{*}{2003} & Admire & 19.8 & 115.0 & 71.1 \\
\hline & Entrust & 17.1 & 97.9 & 70.4 \\
\hline & Conventional insecticide ${ }^{y}$ & 20.2 & 119.3 & 73.7 \\
\hline & Non-treated control & 17.4 & 100.6 & 65.8 \\
\hline & LSD (0.05) & n.s. & n.s. & n.s. \\
\hline \multirow[t]{5}{*}{2004} & Admire & 29.8 a & $160.5 \mathrm{a}$ & $79.1 \mathrm{a}$ \\
\hline & Entrust & 28.8 a & $154.8 \mathrm{a}$ & $78.4 \mathrm{a}$ \\
\hline & Conventional insecticide ${ }^{y}$ & 29.6 a & $162.9 \mathrm{a}$ & $75.7 \mathrm{a}$ \\
\hline & Non-treated control & $22.6 \mathrm{~b}$ & $119.8 \mathrm{~b}$ & $61.4 \mathrm{~b}$ \\
\hline & LSD (0.05) & 3.9 & 22.5 & 9.9 \\
\hline
\end{tabular}

$x$ The number of melons and melon weight are presented per subplot (10 ft row).

y Conventional insecticide was Sevin in 2003 and Sevin alternated with Capture in 2004.

Discussion and I mplications for Management

To our knowledge, this is the first published report that deploying row covers can delay onset and reduce incidence of bacterial wilt in muskmelon. Plots with row covers had greater yield and more marketable melons than plots with no row covers, even though the covers were removed at the start of the bloom period. In additional, plots with row covers received two fewer insecticide applications compared to plots with no row cover. The results suggest that row covers can provide several benefits: enhancement of yield resulting from higher early-season soil temperatures and more rapid plant growth, delay and partial suppression of damage from bacterial wilt, and the reduction of insecticides for management of cucumber beetles.

Row covers have been used successfully to exclude insect pests from broccoli (1), melons (12), and squash $(2,14)$. Furthermore, row covers have been used in cucurbits to exclude insects that are potential vectors of either viruses or bacteria from cucurbits $(2,12,14)$. Also, wilting was minimized, and plant growth was enhanced, with row covers on cucumber and squash (15).

Early in the season in the non-covered rows, the population of striped cucumber beetles was higher than in the covered rows for both years. Striped cucumber beetles colonize cucurbits very early in the season, typically as seedlings emerge or transplants are placed in the field $(5,10)$. The Reemay 
- covered fields were inaccessible to cucumber beetles from transplanting until row cover removal, so the striped beetles fed on the available non-covered plots. After the removal of the row covers, more spotted cucumber beetles were found in the covered than the non-covered plots for both years and more striped cucumber beetles were found in the covered than the non-covered plots in 2004. While the cause of this finding is unclear, behavior of cucumber beetles arriving later in the season may have been influenced by several factors. Cucumber beetles that locate muskmelon fields later in the season may prefer the larger plants in the covered rows. In addition, the surrounding vegetation, as well as the presence or absence of flowers in these surrounding plants, may influence the host preference of the cucumber beetles $(6,8)$.

Data from both years shows that more marketable melons were found in the fields that used row covers in both years. At several sites, the row covers clearly protected the vines from physical damage by thunderstorms and accompanying high winds. Vines that were not covered were visibly damaged from these storms, yet the vines in the covered rows remained unscathed. When row covers were removed, covered plants were consistently larger than those in the uncovered plots. The larger, more vigorous plants combined with protection from early-season beetle feeding may be reasons for the increase in melon yield.

Another possible reason for the increase in melon yield may be related to row covers slowing the dissemination of E. tracheiphila. The impact of delaying wilt during the season may sometimes be minimal since both early and late wilting could severely impact marketability (7). However, if row covers delay of onset of bacterial wilt, they could also delay acquisition of E. tracheiphila by the beetles, and therefore impede dissemination of the pathogen and spread of symptoms.

Do the benefits of row covers outweigh the extra cost and time incurred to set up row covers at the beginning of the season? Considerable labor is needed to set up and remove row covers. However, the row covers do eliminate some insecticide applications and protect the melon plants from two types of serious pests: cucumber beetles and the pathogenic bacteria they carry.

\section{Acknowledgments}

We thank staff at Armstrong Research and Demonstration Farm, Iowa State University Horticultural Station and Muscatine Island Research and Demonstration Farm and the students who assisted with the research. We thank Eric Burkness for editing drafts of this manuscript and Rogers/ Syngenta Seeds Inc. for supplying seed. The work was supported by competitive grants from the USDA Crops at Risk (CAR) program and the North Central Region Sustainable Agriculture Research and Education (SARE) program.

\section{Literature Cited}

1. Adams, R. G., Ashley, R. A., Brennan, M. J . 1990. Row covers excluding insect pests from broccoli and summer squash plantings. J. Econ. Entomol. 83:948-954.

2. Bextine, B., Wayadande, A., Bruton, B. D., Pair, S. D., Mitchell, F., and Fletcher, J. 2001. Effect of insect exclusion on the incidence of yellow vine disease and of the associated bacterium in squash. Plant Dis. 85:875-878.

3. Brown, J. E., and Channell-Butcher, C. 1999. Effects of row cover and black plastic mulch on yield of 'AU Produccer' watermelon on hilled and flat rows. J . Veg. Crop Prod. 5:67-71.

4. Brust, G. E., and Foster, R. E. 1999. New economic threshold for striped cucumber beetle (Coleoptera: Chrysomelidae) in cantaloupe in the Midwest. J . Econ. Entomol. 92:936-940.

5. Deheer, C. J., and Tallamy, D. W. 1991. Affinity of spotted cucumber beetle (Coleoptera: Chrysomelidae) larvae to cucurbitacins. Environ. Entomol. 20:11731175.

6. Hesler, L. S. 1998. Distribution of diabroticine beetles among flowers and other structures of wild host plants in south Texas. S. W. Entomol. 23:361-65.

7. Hubbard N. L., Huber, S. C., Pharr, D. M. 1989. Sucrose phosphate synthase and acid invertase as determinants of sucrose concentration in developing muskmelon (Cucumis melo L.) fruits. Plant Physiol. 91:1527-1534.

8. Lawrence, W. S., and Bach, C. E. 1989. Chrysomelid beetle movements in relation to host-plant size and surrounding non-host vegetation. Ecology 70:1679-1690. 
9. Leach, J. G. 1964. Observations on cucumber beetles as vectors of cucurbit wilt. Phytopathology 54:606-607.

10. Metcalf, R. L., and Metcalf, R. A. 1993. Destructive and Useful Insects Their Habits and Control, 5th Ed. McGraw-Hill, Inc.

11. Motsenbocker, C. E., Bonanno, A. R. 1989. Row cover effects on air and soil temperatures and yield of muskmelon. HortScience 24:601-603.

12. Perring, T. M., Royalty, R. N., and Farrar, C. A. 1989. Floating row covers for the exclusion of virus vectors and the effect on disease incidence and yield of cantaloupe. J. Econ. Entomol. 82:1709-1715.

13. Sherf, A. F., and MacNab, A. A. 1986. Vegetable Diseases and Their Control. J ohn Wiley \& Sons, NY.

14. Webb, S. E., and Stephen, L. B. 1992. Evaluation of spunbonded polyethylene row covers as a method of excluding insects and viruses affecting fall-grown squash in Florida. Entomol. Soc. Am. 85:2344-2352.

15. Wolfe, D. W., Albright, L. D., and Wyland, J . 1989. Modeling row cover effects on microclimate and yield: I. Growth response of tomato and cucumber. J . Amer. Soc. Hort. Sci. 114:562-568. 